\title{
Exploring Predictive Factors Influencing Returning International and American Adult Learners' Motivational Orientations
}

\author{
Xi Lin ${ }^{1} \&$ Chih-hsuan Wang ${ }^{1}$ \\ ${ }^{1}$ Auburn University, Auburn, USA \\ Correspondence: Xi Lin, Department of Educational Foundations, Leadership, and Technology, Auburn University, \\ 4036 Haley Center, Auburn, AL 36849, USA.
}

Received: October 15, 2015

Accepted: November 1, 2015

Online Published: November 4, 2015

doi:10.5430/irhe.v1n1p1

URL: http://dx.doi.org/10.5430/irhe.v1n1p1

\begin{abstract}
This study examined the predictive factors that affect motivational orientations of returning international and American adult learners in higher education. The Educational Participants Scale (EPS/A-form) was used to survey 493 adult learners including both international and American students. Findings indicated that the majority of motivational orientations are different based on distinct student status (International vs. American), gender, age, degree, number of children, years away from previous formal study, and payment methods. Implications of the findings are discussed in the study.
\end{abstract}

Keywords: motivational orientations, adult learners, returning students, international students, higher education

\section{Introduction}

In the past few decades, the number of enrolled adult learners has increased rapidly in colleges and universities across the United States. Statistics report that 8,526 adult students comprised of 3,275 male and 5,251 female adult students were enrolled in degree-granting postsecondary institutions in fall 2012 (Snyder \& Dillow, 2013). The decision of those students to return to school is driven by a variety of motivational orientations (Houle, 1961). As their number continues to grow, it is necessary to understand factors that influence their motivational orientations.

Kasworm, Polson, and Fishback (2002) defined adult learners as 25 years of age and older, and they usually have one or more years away from school before they decided to enroll in postsecondary education. There are several characteristics in this group of students. They usually enroll part time due to full-time employment; they are financially independent of their parents; they usually have families, including their dependents and spouse; sometimes they are single parents; and some of them do not have a high school diploma (National Center for Education Statistics, 1997). Compton et al. (2006) also concluded several characteristics of adult students: first of all, adult students are more likely to pursue programs leading to vocational certificates or degrees; secondly, they have specific goals for their education, such as to gain or enhance work skills; thirdly, adult students consider themselves primarily workers instead of students; finally, they are more likely to take distance education classes. Due to economic issues, many adults may no longer have the necessary skills to become fully employed because of outsourcing and layoffs, so that more and more adults are going back to school in order to improve their work skills or learn new skills to be qualified for positions, and as a result, adult students probably value courses and assignments more that are relevant to their career-focused goals (Compton et al., 2006; Hardin, 2008).

Other major life transitions, such as divorce, widowhood, or career change would influence adult students' willingness to return to higher education (Compton et al., 2006). Ross-Gordon (2003) suggested that change in family situations and personal challenges were significant motivators. Similarly, Aslanian (2001) indicated that many adult students considered education a way of transition from one stage of their life to another.

Moreover, more and more adult women are going back to school and they have become the majority population in postsecondary education (Compton et al., 2006). Research noted that female adult learners returned to college in order to prepare themselves for future jobs and financial security and to support their families. Meanwhile, some of them pursued their self-actualization and returned to school after waiting for children to start school or leave home (Allen, 1993; Hardin, 2008).

Compared with their younger colleagues, getting used to the fast learning pace, solving complex tasks, and time 
constraints may cause frustration and anxiety in adult learners (Breckon, 1982; Campbell \& Lancaster, 1988; Kicklighter, 1991). However, other research considered adult learners more capable of learning than younger students since adult learners bring in their rich life experiences as the foundations to build up their new knowledge base and process new ideas (Richardson \& King, 1998; Ross-Gordon, 2011). Research also demonstrated that adult leaners tended to have different expectations of an institution, different motivation for learning, and different experiences with higher education than their younger colleagues (Richardson \& King, 1998).

According to the above, there are many motivators that encourage adult learners' returning to school. However, their motivators could be influenced by demographic factors such as age, gender, student status, number of children, etc. Therefore, this study examines the relationship between those influential factors and their motivators.

\section{Literature Review}

One of the important studies of motivational orientations in adult learners is Houle's tripartite typology for motivational research. In 1961, Houle interviewed 22 adults and identified three motivational orientations for their returning to school: goal-orientated orientation, activity-oriented orientation, and learning-oriented orientation. Houle (1961) further explained that students with goal-oriented orientation used education as a way for accomplishing a goal, while those with activity-oriented orientation focused on social activity instead of learning itself. In addition, those with learning-oriented orientation focused on learning and seeking for gaining knowledge. Based on Houle's typology, Boshier developed the Educational Participation Scale (EPS) in 1971 and published an alternative EPS form (EPS/A-form) in 1991. The EPS/A-form identifies seven motivational orientations: Communication Improvement (COM), Social Contact (SOC), Educational Preparation (EDUC), Professional Advancement (ADV), Family Togetherness (FAM), Social Stimulation (STIM), and Cognitive Interest (COG). This instrument has been widely used in adult student motivation research (e.g., Bohonos, 2014; Francois, 2014; Gordon, 1992; Stein, Wanstreet, \& Trinko, 2011).

According to EPS (Boshier, 1971), Communication Improvement reflects the desire to improve one's ability to express his/herself through speech or writing; Social Contact reflects the desire for personal association, to make new friends, and to obtain insight into personal issues; Educational Preparation reflects the desire to gain experiences that contribute to or improve one's ability to enter higher education; Professional Advancement reflects the desire to increase job competence or to get higher salary; Family Togetherness reflects the desire to catch up with or share ideas with family members; Social Stimulation reflects the desire to escape the frustrations of day to day living, to get away from loneliness and boredom; Cognitive Interest reflects the desire to learn for the sake of learning and obtain something meaningful out of life.

Occupant pressures, determination to improve job performance, or career change are motivators that drive adult learners to make the decision of coming back to school (Aslanian, 2001; Galbraith \& James, 2002; Ross-Gordon, 2003). Several studies that used EPS illustrated that professional development and professional needs were significant motivators for encouraging adults to return to higher education (Bohonos, 2014; Stein, Wanstreet, \& Trinko, 2011).

Besides Professional Advancement, Cognitive Interest is another vital orientation that strongly motivates adult learners. Gordon (1992) investigated 38 adult learners who received their master's degrees and found that Professional Advancement and Cognitive Interest were rated as the highest among all motivators, while Garst and Ried's (1999) study indicated that adult students' curiosity for knowledge motivated them to learn more than job security. Similarly, Kim and Merriam's (2004) research also supported the idea that adult learners were motivated to learn by Cognitive Interest more than by any other factors.

Researchers also indicated that age is a predictor for cognitive maturity among students (Alexander, Murphy, Woods, Duhon, \& Parker, 1997; Bye et al., 2007; Gadzella, Stephens, \& Baloglu, 2002; Justice \& Dornan, 2001; Macpherson, 2002). According to Wolfgang and Dowling's (1981) study, they surveyed 172 younger students whose age ranged from 18 to 22 as well as 153 older adult students whose age ranged from 23 to 45 , and reported that the adult students had higher scores in Cognitive Interest than the younger students. They also found that the younger students were motivated by the desire for Social Contact, while the adult students were more likely to attend college because they were seeking knowledge for its own sake (Wolfgang \& Dowling, 1981).

Students may have different motivational orientations when they pursue different degrees. Francois (2014) conducted EPS on 162 adult learners at different levels of degree programs. He found that doctoral students had higher scores on Cognitive Interest than master's students, while both nontraditional doctoral and master's degree-seeking students were more primarily motivated by Cognitive Interest than other degree-seeking students. 
Gender may also affect adult students' motivations. Some studies demonstrated that women scored higher on Cognitive Interest (Morstain \& Smart, 1974), while others indicated that Family Togetherness, such as being a good model or providing more opportunities for children, motivated female adult learners to return to school (Clayton \& Smith, 1987; Kerka, 2005; Rodriguez, 1996; Thomas, 2001).

A myriad of studies examined motivational orientations of adult learners, whereas little research investigated demographic factors which may also lead to different motivational orientations comprehensively. Therefore, to fill in the gap, this research probed the relationship between Boshier's seven motivational orientations and demographic factors, including age, gender, student status, degree, number of children, years away from formal study, and tuitions.

\section{Research Questions}

The current study examined the relationship between the seven demographic factors and Boshier's seven motivational orientations. The demographic factors include age, gender, student status (International or American), degree, number of children, years away from formal study, payment of tuitions and fees, whereas the Boshier's seven motivational orientations include Communication Improvement (COM), Social Contact (SOC), Educational Preparation (EDUC), Professional Advancement (ADV), Family Togetherness (FAM), Social Stimulation (STIM), and Cognitive Interest (COG).

\section{Methods}

\subsection{Participants}

Invitation emails were sent out to potential participants who were 25 years old or older and currently enrolled in a master's or doctoral program in a Southeastern research institution. Four hundred and ninety-three participants returned the survey. Among the returned surveys, 362 participants completed the survey and resulted a usable response rate at $82.5 \%$. Among the usable responses, 175 (48.3\%) were male and 187 (51.7\%) were female adult learners. Moreover, $90(24.9 \%)$ of them were international and $272(75.1 \%)$ of them were American adult learners. The proportions of American graduate students and international graduate students in this university are $73.56 \%$ and $26.44 \%$, respectively. A goodness-of-fit test result indicated that the sample can represent the population of this university $\left(X_{(1)}^{2}=0.51, p=.48\right)$.

Among all the participants, $156(43.1 \%)$ were pursing master's degrees, and $206(56.9 \%)$ are pursing doctoral degrees. The participants' age ranged from 25 to $71(\mathrm{M}=33.4, \mathrm{SD}=8.73)$. About $55.5 \%$ of them are married, while $41.2 \%$ of them are single. $61.6 \%$ of them have no children, and $33.2 \%$ of them have 1 or more children. About $70.8 \%$ of the participants reported they were 1 to 5 years away from their prior degree, while $46.1 \%$ of them were more than 5 years away from their previous degree. In addition, most of the international graduate students are from China (40\%) and India (13\%). Others come from countries, such as South Korea, Iran, Turkey, Jordan, Australia, etc.

\subsection{Instrumentation}

The present study used Boshier's Educational Participation Scale/A-Form (EPS/A-Form) and a demographic questionnaire. EPS/A-Form consists of 42 4-point Liker-typed items. Participants rate each item from "no influence" as 1 to "much influence" as 4. The seven motivational orientations in EPS/A-Form are: 1. communication improvement (COM); 2. social contact (SOC); 3. educational preparation (EDUC); 4. professional advancement (ADV); 5. family togetherness (FAM); 6. social stimulation (STIM); 7. cognitive interest (COG). The internal consistency Cronbach's alpha for each motivational orientation ranged from .75 to .95 respectively, while the overall scale is .92 (Fujita-Starch, 1996). The internal consistency Cronbach's alpha for each motivational orientation in this study ranged from .72 to .93 , and the overall scale was .93 .

Ten demographic questions were asked, including age, gender, student status (International or American), degree, number of children, years away from formal study, payment of tuitions and fees. Variables such as gender, student status, degrees, years away from previous formal study, assistance/scholarship from the university, children (yes or no) were dummy coded before analysis.

\subsection{Procedure}

An electronic anonymous survey was hosted by Qualtrics. The invitation email with the link to the survey and the informed consent letter attached was sent out to all graduate students who were 25 years old or older by the Graduate School. The International Student Program also sent the same survey invitation to international students who were identified as adult learners. Data collection lasted from Fall semester 2014 to early Spring semester 2015. The Institution Review Board has approved this study. 


\subsection{Data Analysis}

The present study examines the relationship between the Boshier's seven motivational orientations and demographic factors (age, gender, student status, degree, number of children, years away from formal study, payment of tuitions and fees). The dependent variables were the seven motivational orientations, and the independent variables were the demographic factors. A multiple linear regression was used to examine the correlation of those variables via SPSS version 23. The significant level was set at alpha $=.05$.

\section{Results}

\subsection{Communication Improvement (COM)}

A linear multiple regression with stepwise procedure was conducted to predict COM based on the demographic factors. About $58.2 \%$ of variances in COM can be accounted by the students' status (international or American) and the interaction between gender and students' status $\left(R^{2}=.58\right)$. The regression model was statistically significant $\left(\mathrm{F}_{(2}\right.$, $\left.{ }_{359)}=92.053, p<.001\right)$. Results indicated that when the interaction between gender and status remains the same, COM scores of international students are 1.18 units higher than American students $(\mathrm{t}(2)=10.71, p<.001)$, whereas for both international and American students, COM scores decrease by 0.37 units when the interaction effect on gender and status increases every unit $(\mathrm{t}(2)=-2.86, p=.004)$. Furthermore, data indicated that male international adult learners have a stronger COM than male American adult students. Similarly, female international students' COM scores are higher than that of female American students. In addition, female international students have higher COM scores than male international students (see Figure 1).

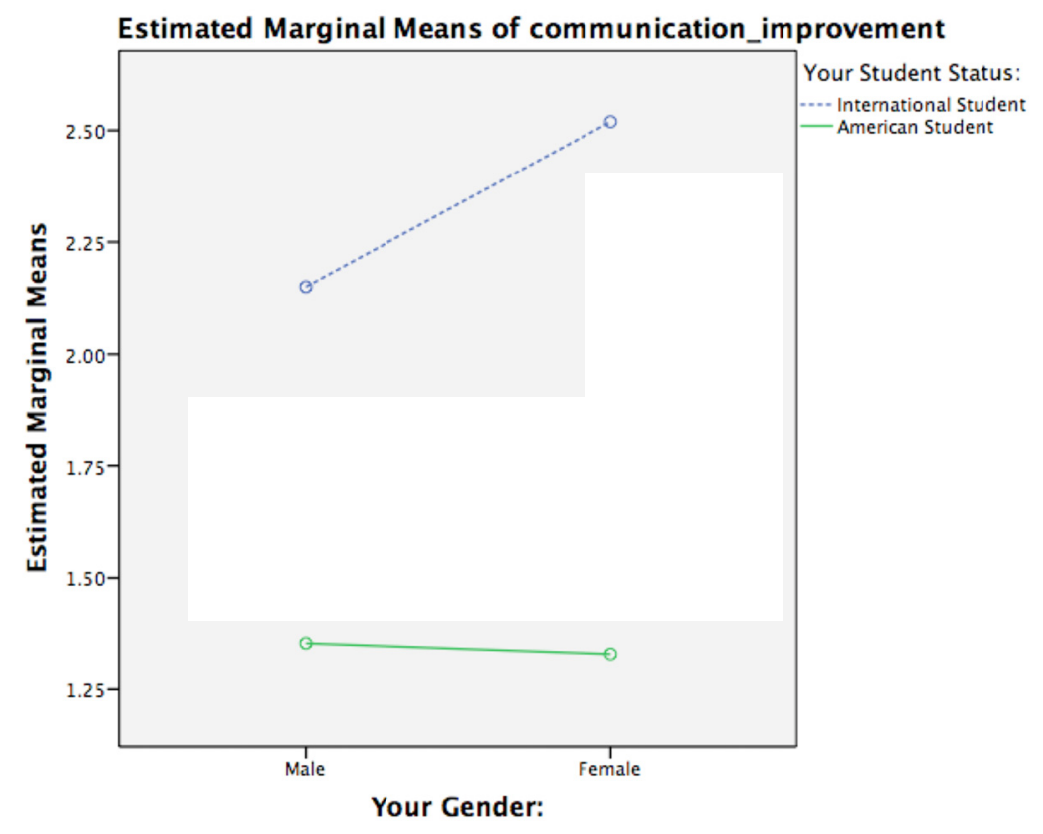

Figure 1. Interaction effect of gender and student status (COM)

\subsection{Social Contact (SOC)}

Using demographic questions to predict the adult learners' motivation in SOC yielded a $47.2 \%$ of variances in SOC. This can be accounted by students' status, years away from previous degree, and the interaction between gender and students' status $\left(R^{2}=.47\right)$. The regression model was statistically significant $\left(\mathrm{F}_{(3,358)}=34.29, p<.001\right)$. Results indicated that while the years away from previous degree and interaction effect remains the same, international students have 0.883 units higher scores of SOC than American students ( $\mathrm{t}(3)=7.49, p<.001)$. In addition, adult students who are 5 or more years away from their previous formal study have 0.176 units higher in SOC scores than those who are less than 5 years away from their previous formal study while all other factors remain the same $(\mathrm{t}(3)=-2.48, p=.01)$. Finally, for both international and American students, for every unit the interaction effect of gender and status increased, their SOC score decreased by 0.319 units $(\mathrm{t}(3)=-2.33, p=.02)$. Results showed that male 
international students' SOC scores are higher than that of male American students, and it is similar when compared to female international students and female American students (see Figure 2).

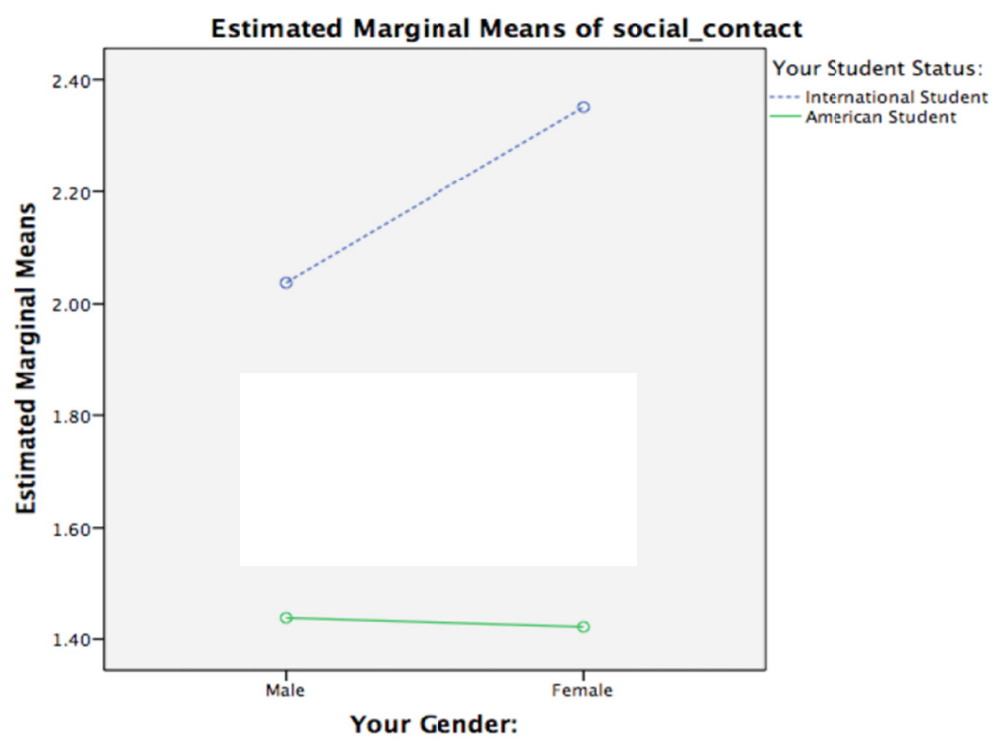

Figure 2. Interaction effect of gender and student status (SOC)

\subsection{Educational Preparation (EDUC)}

Using demographic questions to predict the EDUC, about $30.0 \%$ of variance in EDUC can be accounted by students' status $\left(R^{2}=.30\right)$. The regression model was statistically significant $\left(\mathrm{F}_{(1,360)}=35.537, p<.001\right)$. Based on the results, the international students scored 0.45 units higher in EDUC than American students did $(\mathrm{t}(1)=5.96, p<.001)$.

\subsection{Professional Advancement (ADV)}

Using demographic factors to predict adult learners' ADV scores, about $14.6 \%$ of variance in ADV can be accounted by the age of the adult learners $\left(R^{2}=.146\right)$. The regression model was statistically significant $\left(\mathrm{F}_{(1,360)}=7.82, p\right.$ $=.005)$. Results indicated that adult learners are less motivated by ADV orientation for pursing learning when they become older $(\mathrm{t}(1)=-2.80, p=.005)$.

\subsection{Family Togetherness (FAM)}

Using demographic factors to predict adult learners' FAM scores, about $49.4 \%$ of variance in FAM can be accounted by the students' status $\left(R^{2}=.494\right)$, having or not having children, and having or not having a scholarship. The regression model was statistically significant $\left(\mathrm{F}_{(3,358)}=38.49, p<.001\right)$. Results indicated that when all other factors remain the same, international students scored 0.502 units higher in FAM than American students did $(\mathrm{t}(3)=9.68$, $p<.001)$. Furthermore, adult learners who have children scored 0.214 units higher than those who do not have any dependents when other conditions remain the same $(\mathrm{t}(3)=4.65, p<.001)$. Finally, adult students who get university assistantship or scholarship scored 0.103 units in FAM less than those who pay other ways when other conditions remained the same $(\mathrm{t}(3)=-2.26, p=.02)$.

\subsection{Social Stimulation (STIM)}

Using demographic factors to predict the STIM scores, about 30.5\% of variance in STIM scores can be accounted by the students' status and the interaction between gender and students' status $\left(R^{2}=.305\right)$. The regression model was statistically significant $\left(\mathrm{F}_{(2,359)}=18.38, p<.001\right)$. The result illustrated that international adult students scored 0.542 units in STIM higher than American students when the interaction effect of gender and status remains the same $(\mathrm{t}(2)=5.41, p<.001)$, while STIM score decreased by 0.28 units when the synergy effect of gender and status increase for every unit for both international and American adult learners $(\mathrm{t}(2)=-2.39, p=.02)$. Furthermore, female adult students had higher STIM scores than male adult students (see Figure 3). 


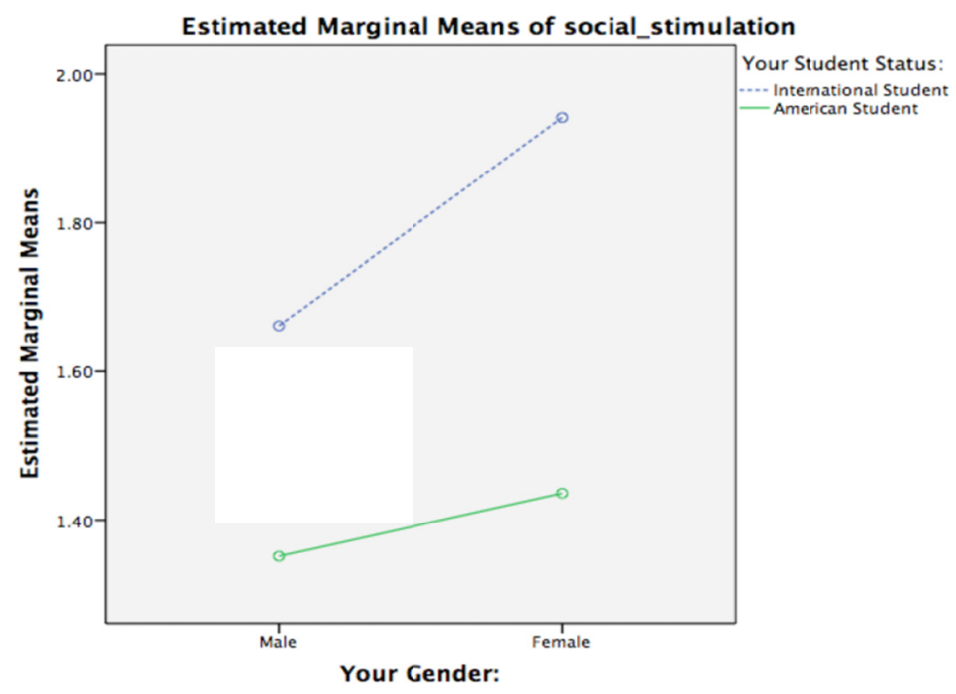

Figure 3. Interaction effect of gender and student status (STIM)

\subsection{Cognitive Interest (COG)}

Using demographic factors to predict COG scores, about $15.1 \%$ of variance in COG scores can be accounted by the degree the adult learners were pursuing $\left(R^{2}=.151\right)$. The regression model was statistically significant $\left(\mathrm{F}_{(1,360)}=8.44\right.$, $p=.004)$,. Results indicated that adult learners who pursue doctoral degrees scored 0.235 units in COG higher than those who pursue master's degrees $(\mathrm{t}(1)=2.91, p=.004)$.

\section{Discussion and Implications}

Findings indicate that the majority of motivational orientations are different based on their student status (international or American students), gender, age, degree, having children or not, as well as receiving university scholarship or not.

Adult learners have different motivational orientations based on whether they are international students or American students. This result supports Lin and Wang's (2015) research that international adult students, both male and female, have higher Communication Improvement, Social Contact, Educational Preparation, Family Togetherness, and Social Stimulation than American adult learners. In other words, international adult learners may have a stronger desire to improve their ability to express themselves through speech or writing, and they are more enthusiastic to make new friends. Moreover, results indicate that international adult students have stronger ambition to do better prepration for making up education that they missed in their early life and for futher education. International adult students also have a stronger determination to catch up with or share ideas with family members, and they are eager to explore a different life style. It may be hypothesized that international students' characteristics, such as learning English as a second language, carrying different educational attitudes that were nurtured by their own cultures, etc, play a part in forming their motivations, and future research could further investigate this assumption. In addition, female international students have higher scores in Social Stimulation than male international students. Besides Cognitive Interest and Family Togetherness (e.g., Clayton \& Smith, 1987; Kerka, 2005; Morstain \& Smart, 1974), this finding suggests that female adult students may return to school due to their stronger desire to seek for a new life experience.

In addition, results illustrate that Professional Advancement scores decrease as students' ages increase. This finding also supports previous research that older adult students were more likely to seek self-actualization instead of career improvement (Francois, 2014; Wolfgang \& Dowling, 1981). This result may also imply that some older adult students are more financially secure compared with younger adult learners, meaning that they do not have to worry about financial issues and could pursue knowledge for its own sake.

Findings of the present study also support Francois' (2014) conclusion that doctoral students have higher Cognitive Interest scores than master's students. It may be hypothesized that adult learners who seek doctoral degrees are probably more eager to figure out the mysteries and explore the why of an issue, whereas those who pursue master's degrees may prefer to learn more practical skills and learn the how of solving a problem. More research is needed towards this assumption.

Another compelling finding is that adult learners who have children have higher Family Togetherness scores than those who do not. Meanwhile, those who obtain university assistantship or scholarship have less Family 
Togetherness than those who pay tuition other ways. Further investigation showed that among the adult learners who do not have children, $47.98 \%$ of them pay tuition other ways, and $52.02 \%$ of them pay through university assistantship or scholarship. However, for those who have children, $64.03 \%$ of them pay their tuition fees other ways, whereas $35.97 \%$ of them pay by assistantship or scholarship $\left(\chi_{(1)}^{2}=8.88, p=.003\right)$. It could be that the adult learners who do not have children are more likely to receive university assistantship or scholarship, or that those who have children usually do not need the support from the university.

There are several limitations in this study. Firstly, survey questions were based on self-reporting and relied on the understanding and truthfulness of the participants. Moreover, since this research was restricted to one institution, the responses of the participants may be influenced by this university's culture so that the results may not represent all the returning adult learners enrolled in higher education in the United States. Lastly, the present study only recruited master's and doctoral students. Returning adult learners who are pursing undergraduate degrees may provide different results. Future research could investigate the influence of international adult students' characteristics on their motivations. In addition, research could further analyze adult learners' motivations, especially Cognitive Interest, based on the different degrees they are pursing. Qualitative research such as a focus group would be a suggested method to investigate reasons for seeking different degrees among returning adult learners. Moreover, further study on Family Togetherness could be conducted based on different number of children and different ways of financial support.

In conclusion, this study sheds light on the relationship of demographic factors of adult learners to their motivational orientations. Results indicated several ways for higher education professionals to better serve this special group. For example, faculty members may design the course curriculum in a slightly different way, depending on the distinct degrees that adult students are pursuing. Moreover, universities and colleges may consider providing programs to help international students form meaningful friendships with local students and to help them experience local culture in order to to recruit more international students. Universities and colleges may also consider offering programs that focus on practice and application of skills as a way to attract more adult students of a younger age. Finally, it is expected that this study will lead to a greater awareness of adult learners' characteristics and their needs. It is also hoped that this research can enlighten higher education professionals with practical ideas and plans to create a better campus environment and climate to better serve this growing population.

\section{References}

Alexander, P. A., Murphy, P. K., Woods, B. S., Duhon, K. E., \& Parker, D. (1997). College instruction and concomitant changes in students' knowledge, interest, and strategy use: A study of domain learning. Contemporary Educational Psychology, 22(2), 125-146.

Allen, B. A. (1993). The student in higher education: Nontraditional student retention. Community Services Catalyst, 23(3), 19-22.

Aslanian, C. (2001). You're Never Too Old... Excerpts from "Adult Students Today". Community College Journal, $71(5), 56-8$.

Bohonos, J. (2014). Understanding career context as a key to best serving adult students. Adult Learning, 25(1), 28-30. http://dx.doi.org/10.1177/1045159513510144

Boshier, R. (1971). Motivational orientations of adult education participants: A factor analytic exploration of Houle's typology. Adult Education Quarterly, 21(2), 3-26. http://dx.doi.org/10.1177/074171367102100201

Breckon, D. J. (1982). Hospital health education: a guide to program development. Aspen Systems Corporation.

Bye, D., Pushkar, D., \& Conway, M. (2007). Motivation, interest, and positive affect in traditional and nontraditional $\begin{array}{lllll}\text { undergraduate students. } & \text { Adult education }\end{array}$ http://dx.doi.org/10.1177/0741713606294235

Campbell, J. M., \& Lancaster, J. (1988). Communicating effectively with older adults. Family \& Community Health, 11(3), 74-85.

Clayton, D. E., \& Smith, M. M. (1987). Motivational typology of reentry women. Adult Education Quarterly, 37(2), 90-104. http://dx.doi.org/10.1177/0001848187037002003

Compton, J. I., Cox, E., \& Laanan, F. S. (2006). Adult learners in transition. New directions for student services, 2006(114), 73-80. http://dx.doi.org/10.1002/ss.208

Francois, E. J. (2014). Motivational orientations of non-traditional adult students to enroll in a degree-seeking program. New Horizons in Adult Education and Human Resource Development, 26(2), 19-35. http://dx.doi.org/10.1002/nha3.20060

Fujita-Starck, P. J. (1996). Motivations and characteristics of adult students: Factor stability and construct validity of 
Tie educational participation scale. Adult Education Quarterly, 47(1), 29-40. http://dx.doi.org/10.1177/074171369604700103

Gadzella, B. M., Stephens, R., \& Baloglu, M. (2002). Prediction of Educational Psychology Course Grades by Age and Learning Style Scores. College Student Journal, 36(1), 62.

Galbraith, M. W., \& James, W. B. (2002). Implications of social role research for community colleges. Community College Journal of Research and Practice, 26(6), 521-533. http://dx.doi.org/10.1080/02776770290041873

Garst, W. C., \& Ried, L. D. (1999). Motivational orientations: evaluation of the education participation scale in a nontraditional doctor of pharmacy program. American journal of pharmaceutical education, 63, 300-304.

Gordon, H. R. (1992). Analysis of the motivational orientations of adult education graduates in off-campus credit programs. EDRS Report, Marshall University, West Virginia.

Hardin, C. J. (2008). Adult students in higher education: A portrait of transitions. New directions for higher education, 2008(144), 49-57. http://dx.doi.org/10.1002/he.325

Houle, C. O. (1961). The inquiring mind. Madison: University of Wisconsin Press.

Justice, E. M., \& Dornan, T. M. (2001). Metacognitive differences between traditional-age and nontraditional-age college students. Adult Education Quarterly, 51(3), 236-249. http://dx.doi.org/10.1177/074171360105100305

Kasworm, C. E., Polson, C. J., \& Fishback, S. J. (2002). Responding to Adult Learners in Higher Education. Professional Practices in Adult Education and Human Resource Development Series. Krieger Publishing Company, PO Box 9542, Melbourne, FL 32902-9542.

Kerka, S. (2005). Learner Persistence in Adult Basic Education. California Adult Education Research Digest, 2, 1-4.

Kicklighter, J. R. (1991). Characteristics of older adult learners: a guide for dietetics practitioners. Journal of the American Dietetic Association, 91(11), 1418-1422.

Kim, A., \& Merriam, S. B. (2004). Motivations for learning among older adults in a learning in retirement institute. Educational Gerontology, 30(6), 441-455. http://dx.doi.org/10.1080/03601270490445069

Lin, X., \& Wang, C. H. (2015). Factors that Affect Returning to Graduate School for International and American Adult Learners. Institute for Learning Styles Journal, 1, 40. Retrieved from http://www.auburn.edu/academic/education/ilsrj/Journal\%20Volumes/Fall\%202015\%20Vol\%201\%20PDFs/Lin \%20Wang\%20Factors\%20Affecting\%20Grad\%20Students.pdf

Macpherson, K. (2002). Problem-solving ability and cognitive maturity in undergraduate students. Assessment \& Evaluation in Higher Education, 27(1), 5-22. http://dx.doi.org/10.1080/02602930120105027

Morstain, B. R., \& Smart, J. C. (1974). Reasons for participation in adult education courses: A multivariate analysis of group differences. Adult Education Quarterly, 24(2), 83-98. http://dx.doi.org/10.1177/074171367402400201

National Center for Education Statistics. (1997). Median age of enrolled students and the percent of enrolled students who are under 25 in Title IV eligible degree-granting institutions, by student level, attendance status, and sex; 50 states and the District of Columbia [Online]. Retrieved August 24, 2000, from http://nces.ed.gov

Richardson, J. T., \& King, E. (1998). Adult students in higher education: burden or boon? Journal of Higher Education, 69(1), 65-88.

Rodriguez, S. (1996). Detour from Nowhere: The Remarkable Journey of a Re-Entry College Woman. Initiatives, $58(1), 1-10$.

Ross-Gordon, J. M. (2003). Adult learners in the classroom. New Directions for Student Services, 2003(102), 43-52.

Ross-Gordon, J. M. (2011). Research on adult learners: Supporting the needs of a student population that is no longer nontraditional. Peer Review, 13(1), 26-29.

Snyder, T. D., \& Dillow, S. A. (2013). Digest of Education Statistics, 2012. NCES 2014-015. National Center for Education Statistics.

Stein, D. S., Wanstreet, C., \& Trinko, L. A. (2011). From consideration to commitment: Factors in adults' decisions to enroll in a higher education degree program. The Journal of Continuing Higher Education, 59(2), 68-76. http://dx.doi.org/10.1080/07377363.2011.568820

Thomas, V. G. (2001). Educational experiences and transitions of reentry college women: Special considerations for African American female students. Journal of Negro Education, 70(3), 139-155. http://dx.doi.org/10.2307/3211206

Wolfgang, M. E., \& Dowling, W. D. (1981). Differences in motivation of adult and younger undergraduates. The Journal of Higher Education, 52(6), 640-648. http://dx.doi.org/10.2307/1981772 